\title{
Edukasi Keamanan Vaksin dan Pembagian Sembako, Masker serta Vitamin C Gratis Sebagai Upaya Pencegahan Penularan COVID-19 di Kelurahan Lasiana Kota Kupang
}

\author{
Jannes Bastian Selly ${ }^{*}$, Istha Leanni Muskananfola ${ }^{2}$ \\ Universitas Citra Bangsa, Jln. Manafe No. 17, Kelurahan Kayu Putih, Kota Kupang, Nusa Tenggara \\ Timur. 85111 \\ E-mail: bastian.jannes04@ gmail.com ${ }^{1 *}$
}

(Diajukan: 07 Juli 2021, Direvisi: 01 Agustus 2021, Diterima: 04 September 2021)

\begin{abstract}
ABSTRAK
Peningkatan kasus infeksi Corona Virus Disease 2019 (COVID-19) kembali terjadi di Indonesia pada awal Bulan Juli Tahun 2021. Beberapa wilayah dengan kasus penularan yang tinggi, ditetapkan pemerintah untuk melakukan Pemberlakuan Pembatasan Kegiatan Masyarakat (PPKM), salah satunya adalah di Kota Kupang, Provinsi Nusa Tenggara Timur (NTT). Implementasi dari edaran Wali Kota Kupang menyebabkan beberapa masyarakat yang hanya bekerja serabutan mengalami kesulitan dalam aktifitas mencari nafkah. Selain itu juga adanya pemahaman yang keliru mengenai vaksin, sehingga sebagian besar masyarakat belum bersedia mengikuti vaksin COVID-19. Oleh karena itu sebagai upaya edukasi sekaligus bantuan bagi masyarakat, maka dilakukan bakti sosial berupa edukasi keamanan vaksin serta pembagian sembako, masker dan vitamin C di Kelurahan Lasiana, Kota Kupang. Total bantuan sebanyak 25 Paket berisi beras, telur, minyak goreng, gula, sabun cuci, masker medis, vitamin $\mathrm{C}$, serta materi edukasi yang dicetak dalam bentuk brosur. Melalui kegiatan ini, masyarakat penerima bantuan merasa terbantu, dan juga memahami betul pentingnya mengikuti vaksin COVID19. Diharapkan agar pemerintah setempat RT dan RW melakukan tindak lanjut untuk memastikan semua warga yang memenuhi kriteria penapisan dapat melakukan vaksin.
\end{abstract}

Kata Kunci: Sembako, Masker, Vitamin C, Materi Edukasi Vaksin, COVID-19, PPKM

\section{ABSTRACT}

The increase in cases of Corona Virus Disease 2019 (COVID-19) infection again occurred in Indonesia in early July 2021. Several areas with high transmission cases, the government set out to implement Community Activity Restrictions (PPKM), one of which was in Kupang City, East Nusa Tenggara (NTT) Province. The implementation of the circular from the Mayor of Kupang has caused some people who only work odd jobs to have difficulty in earning a living. In addition, there is also a misunderstanding about vaccines, so most people are not willing to take the COVID-19 vaccine. Therefore, as an effort to educate and help the community, social services were carried out in the form of vaccine safety education and distribution of basic necessities, masks and vitamin $C$ in Lasiana Village, Kupang City. Total of 25 packages containing rice, eggs, cooking oil, sugar, laundry soap, medical masks, vitamin $C$, as well as educational materials were printed in the form of brochures. Through this activity, the recipients of the aid feel helped, and also understand very well the importance of following the COVID-19 vaccine. It is hoped that the local $R T$ and $R W$ governments will follow up to ensure that all residents who meet the screening criteria can get the vaccine.

Keywords: Basic needs, Mask, Vitamin C, Brochure about vaccine, COVID-19, PPKM 


\section{PENDAHULUAN}

Penyebaran COVID-19 di Indonesia telah berlangsung selama 16 bulan terhitung sejak kasus positif pertama di bulan Maret 2020. Dalam kurun waktu tersebut, pasien yang terkonfirmasi positif, secara nasional sudah lebih dari 2 juta orang. Pada awal bulan Juli tahun 2021, terjadi lonjakan kasus positif harian hingga lebih dari 30 ribu kasus per hari. Data per tanggal 06 Juli 2021 menunjukkan terjadi lonjakan kasus terkonfirmasi positif COVID-19 sebesar 31.189 kasus per hari, yang dapat dilihat dalam grafik pada Gambar 1 (Komite Penanganan COVID-19 dan Pemulihan Ekonomi Nasional, 2021).

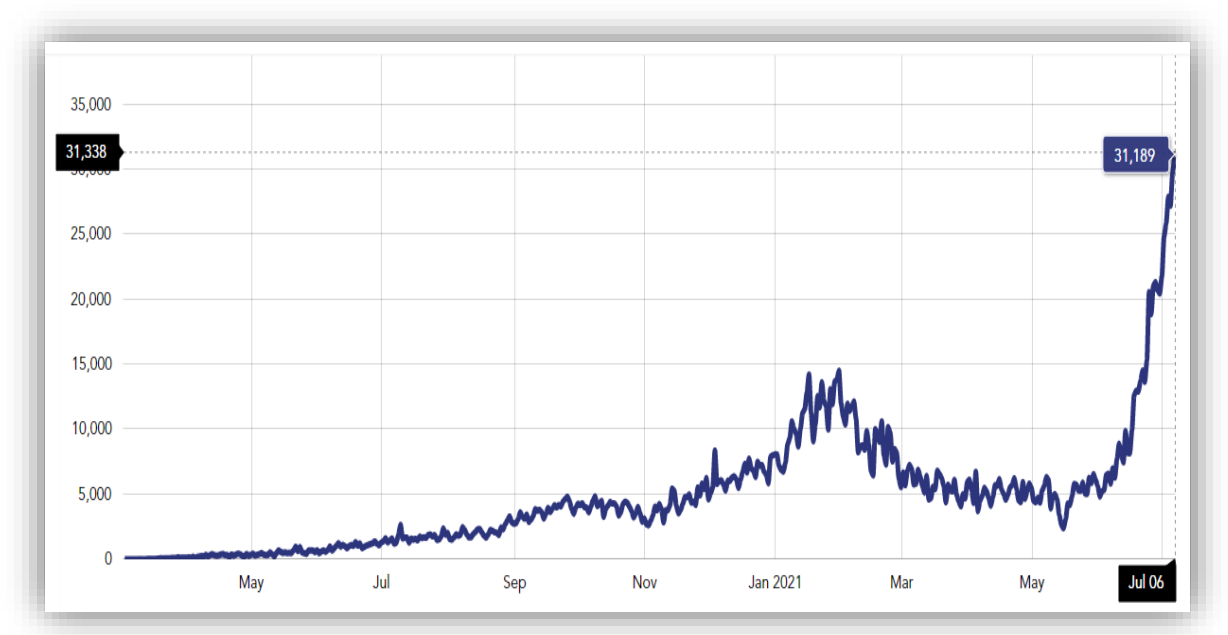

Gambar 1. Penyebaran jumlah kasus terkonfirmasi positif COVID-19 di

Indonesia. Sumber: Komite Penanganan COVID-19 dan Pemulihan Ekonomi Nasional (https://covid19.go.id/peta-sebaran-covid19)

Kondisi ini membuat pemerintah segera mengambil langkah antisipatif dengan Pemberlakuan Pembatasan Kegiatan Masyarakat (PPKM) melalui Instruksi Menteri Dalam Negeri Nomor 15 Tahun 2021 tentang PPKM Darurat COVID-19 di Wilayah Jawa dan Bali (Kementerian Dalam Negeri, 2021). Kebijakan ini dilakukan sebagai upaya menekan jumlah penyebaran COVID-19 di daerah dengan kasus tertinggi. Selain Jawa dan Bali, lonjakan kasus terkonfirmasi positif COVID-19 juga terjadi di wilayah Provinsi Nusa Tenggara Timur (NTT).

Kasus positif COVID-19 harian tertinggi di NTT mengalami lonjakan cukup tajam hingga mencapai 1033 kasus pada tanggal 4 Juli 2021. Data per tanggal 07 Juli 2021 menunjukkan bahwa jumlah masyarakat yang terkonfirmasi positif COVID-19 baik yang 
menunjukkan gejala maupun tanpa gejala sebanyak 20.971 orang, dimana 17.233 orang diantaranya telah dinyatakan sembuh, dan 512 orang lainnya meninggal dunia seperti yang ditunjukkan dalam Gambar 2 (Gugus Tugas Percepatan Penanganan COVID-19 NTT, 2021).

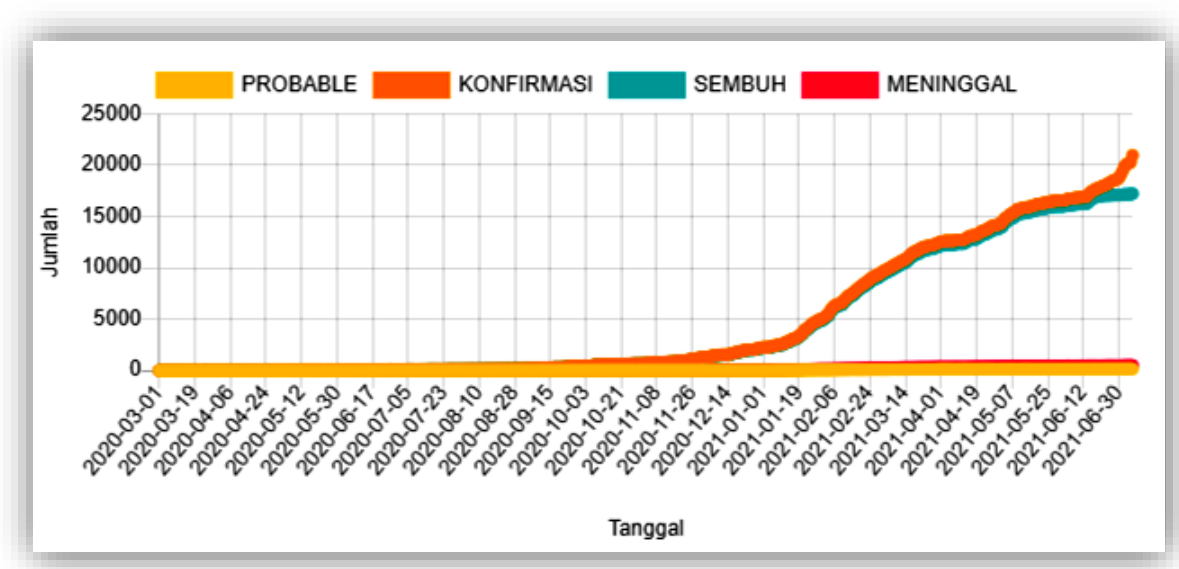

Gambar 2. Perkembangan jumlah data surveillance COVID-19 di Provinsi NTT. Sumber: Gugus Tugas Percepatan Penanganan COVID19 NTT (http://www.covid19.nttprov.go.id/home/data)

Penelitian yang dilakukan oleh MacIntyre dkk (2021) menggunakan pemodelan matematis deterministik terhadap populasi masyarakat di New South Wales (NSW), Australia, menunjukkan bahwa vaksinasi masal dapat meningkatkan kekebalan tubuh komunitas masyarakat di suatu wilayah. Persamaan matematis untuk menghitung cakupan vaksin untuk mencapai tingkat kekebalan kelompok masyarakat (herd immunity) adalah sebagai berikut.

$$
V_{c}=\frac{1}{V_{e}} \times\left(1-\frac{1}{R_{0}}\right)
$$

dimana, $\mathrm{V}_{\mathrm{c}}$ merupakan nilai cakupan vaksin, $\mathrm{V}_{\mathrm{e}}$ merupakan tingkat efikasi vaksin (dalam pemodelan digunakan $90 \%$ ) dan $\mathrm{R}_{0}$ merupakan nilai yang diasumsikan dapat menghasilkan herd immunity yaitu sebesar 2.5, berdasarkan simulasi hasil perhitungan yang dilakukan oleh CDC. Hasil pemodelan berupa kurva yang menunjukkan kemungkinan insiden kasus, kasus kumulatif dan kumulatif kematian pada masyarakat dapat dilihat pada gambar 3 (MacIntyre dkk, 2021). 

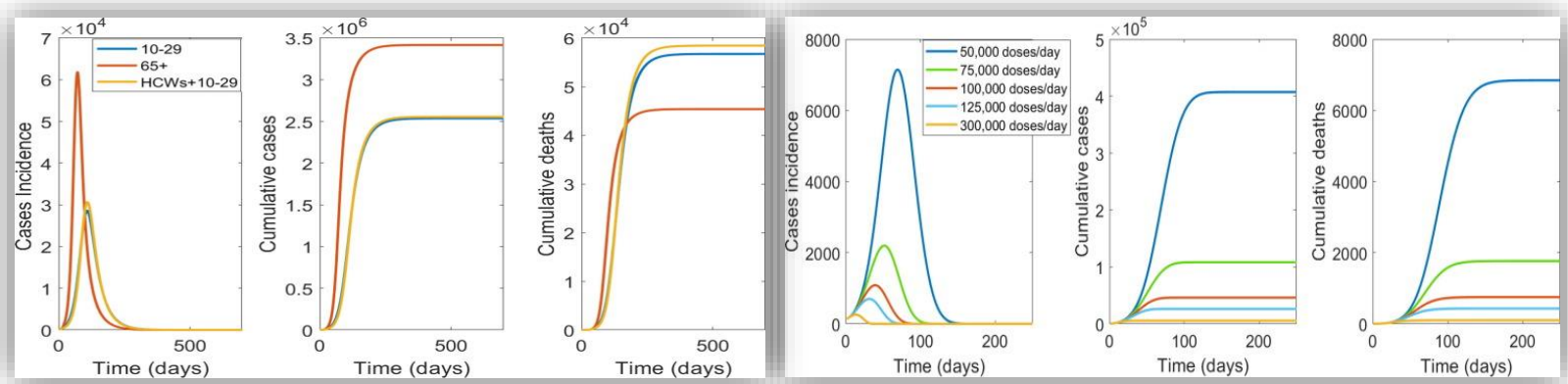

a
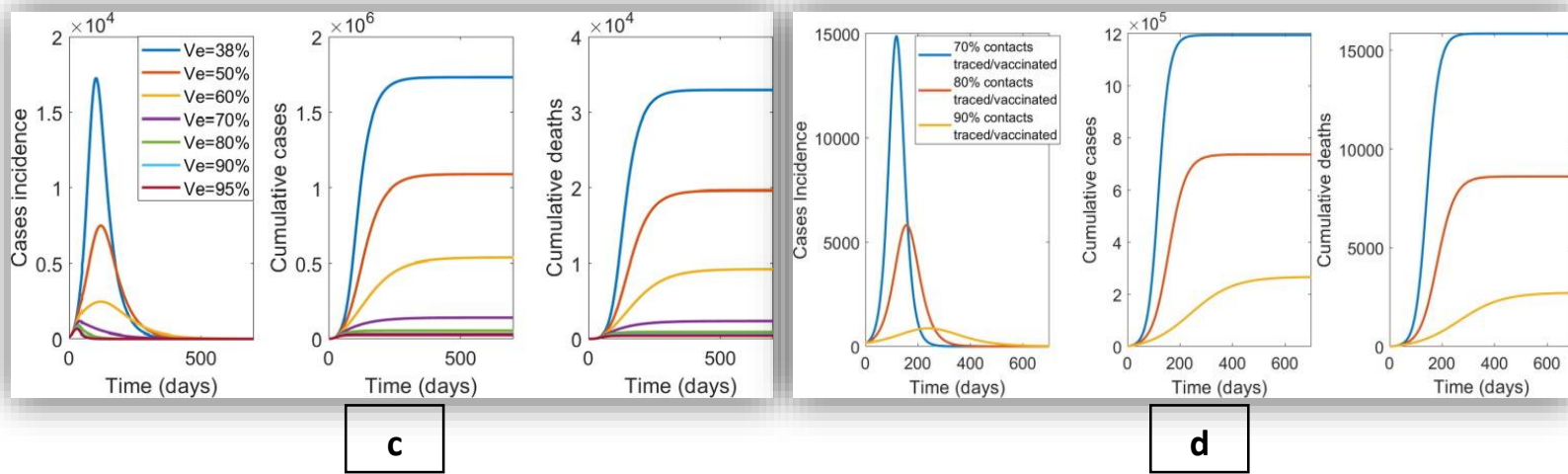

Gambar 3. Kurva hasil pemodelan matematis terhadap berbagai kemungkinan insiden kasus, kasus kumulatif dan kumulatif kematian pada masyarakat NSW, Australia pasca dilakukan vaksin (MacIntyre dkk, 2021).

Hasil simulasi berdasarkan model matematis yang dibuat menunjukkan bahwa vaksin yang diberikan pada kelompok usia muda berdampak nyata terhadap penurunan jumlah kasus inveksi COVID-19, sedangkan vaksin pada usia 65+ lebih berdampak pada penurunan resiko kematian (Gambar 3a). Selanjutnya hasil simulasi juga menunjukkan bahwa semakin banyak masyarakat yang memperoleh vaksin setiap harinya dapat membuat kondisi pandemi lebih cepat berakhir (Gambar 3b), selanjutnya hasil simulasi menunjukkan bahwa makin tinggi tingkat efikasi vaksin, akan menurunkan insiden kasus lebih cepat dibandingkan dengan efikasi vaksin yang rendah. Tingkat efikasi vaksin $\leq 60 \%$ menyebabkan penularan akan terus terjadi dan resiko pandemi akan terus berlanjut (Gambar 3c). Hasil lain menunjukkan bahwa semakin tinggi proporsi kontak yang dilacak dan diberikan vaksin, maka dampak pandemi akan semakin menurun. Dalam skenario yang dilakukan, jika pelacakan dan pemberian vaksin $\leq 70 \%$, maka dampak pandemik akan lebih besar dibandingkan dengan proporsi $80 \%$ dan 90\% (Gambar 3d) (MacIntyre dkk, 2021). 
Data yang diperoleh dari Kementerian Kesehatan, menunjukkan bahwa dari keseluruhan jumlah masyarakat NTT yang dapat menerima vaksin, hanya sekitar $21 \%$ yang sudah menerima vaksin lengkap (Kementerian Kesehatan RI, 2021). Kondisi ini mungkin saja dipengaruhi oleh informasi yang keliru mengenai vaksin COVID-19, sehingga masyarakat ragu bahkan takut melakukan vaksin. Asumsi ini didasari oleh hasil penelitian yang dilakukan oleh Priastuti dkk, tahun 2020. Hasil penelitian yang dilakukan menunjukkan bahwa keberadaan informasi yang keliru mengenai COVID-19 dan upaya vaksinasi di berbagai media sosial berdampak terhadap krisis kepercayaan pada pemerintah dan sikap apatis terhadap pandemi COVID-19 (Priastuti dkk, 2020). Hasil penelitian yang juga mendukung asumsi ini, dilakukan terhadap 3.133 orang dewasa di Amerika Serikat menunjukkan bahwa informasi yang keliru mengenai vaksin COVID-19, menyebabkan masyarakat masih ragu bahkan tidak percaya dengan keamanan vaksin. Hal ini kemudian berdampak terhadap keputusan masyarakat untuk melakukan vaksin (Thunstrom dkk, 2020; Dewi dkk, 2021). Oleh karena itu perlu dilakukan edukasi kepada masyarakat terkait pandemi COVID-19 dan kemanan vaksin sehingga masyarakat tidak lagi percaya pada informasi yang keliru di media sosial.

Kota Kupang sebagai ibukota provinsi, sekaligus menjadi salah satu daerah yang memiliki jumlah kasus positif COVID-19 paling tinggi di NTT. Data per tanggal 05 Juli 2021 menunjukkan bahwa, dari total 51 kelurahan yang ada di Kota Kupang, hanya 2 kelurahan yang berada dalam kategori zona hijau (tidak terdapat kasus aktif COVID-19), sedangkan pada zona kuning sebanyak 12 kelurahan, oranye sebanyak 10 kelurahan dan 27 kelurahan berada dalam zona merah (Satgas COVID-19 Pemkot Kupang, 2021). Kondisi ini membuat pemerintah Kota Kupang mengambil kebijakan untuk menerapkan PPKM skala mikro bagi masyarakat. Kebijakan ini termuat dalam surat edaran Wali Kota Kupang Nomor 041/HK.443.1/VII/2021 tentang perpanjangan penebalan PPKM skala mikro di Kota Kupang sebagai upaya pengendalian penularan COVID-19. (Pemerintah Kota Kupang, 2021).

Kondisi pandemi COVID-19 yang telah berlangsung lebih dari 1 tahun, serta pelaksanaan PPKM skala mikro di Kota Kupang yang sudah beberapa kali diterapkan, secara langsung berdampak pada pendapatan masyarakat pelaku usaha khususnya non-ASN. Pendapatan masyarakat mengalami penurunan dibandingkan sebelum pandemi, sebagaimana hasil survey yang dilakukan oleh BPS Provinsi NTT. Hasil survei menunjukkan bahwa 
sebanyak $73.25 \%$ masyarakat mengatakan bahwa jumlah pendapatan mereka menurun saat masa pandemik COVID-19 (BPS NTT, 2020:8). Oleh karena itu, perlu dilakukan edukasi bagi masyarakat untuk memberikan pemahaman yang benar mengenai kondisi pandemik COVID19 yang dialami saat ini serta pentingnya melakukan vaksin sehingga dapat terbentuk kekebalan komunitas masyarakat di wilayah tersebut. Bersamaan dengan pelaksanaan ini, juga dilakukan pembagian sembako, masker dan vitamin C gratis bagi masyarakat. Hal ini dilakukan mengingat dalam masa PPKM mikro yang diterapkan di Kota Kupang selama 2 minggu mulai tanggal 5 hingga 21 Juli, membuat kegiatan masyarakat menjadi terbatas, sehingga diharapkan bantuan sembako gratis memiliki kontribusi dalam meringankan beban masyarakat, khususnya yang tidak memiliki pekerjaan tetap. Masker dan vitamin $\mathrm{C}$ yang dibagikan juga menunjang masyarakat untuk menjalankan protokol kesehatan yang disarankan oleh pemerintah.

\section{METODE}

Pengabdian dilakukan dalam bentuk penyuluhan, sekaligus membagikan bantuan berupa sembako, masker dan vitamin $\mathrm{C}$ bagi masyarakat. Tim pengabdian terdiri dari dua orang dosen dari Fakultas Kesehatan Universitas Citra Bangsa. Penulis 1 merupakan dosen dengan latar belakang keilmuan Fisika Medis dan Biofisika, sedangkan penulis 2 merupakan dosen dengan latar belakang keilmuan Keperawatan. Dalam penelitian ini tidak melibatkan mahasiswa, untuk menghindari terjadinya kerumunan, mengingat pelaksanaan kegiatan dilakukan dalam masa PPKM mikro. Pembiayaan dalam kegiatan ini sepenuhnya dari swadaya tim pengabdian. Mitra dalam kegiatan ini merupakan pemerintah setempat dalam hal ini adalah ketua RW 009, bersama dengan ketua RT 032, 033 dan 034, yang merupakan wilayah di bawah cakupan RW 009 Kelurahan Lasiana.

Lokasi pengabdian yang dipilih adalah di kelurahan lasiana, sebab kelurahan lasiana menjadi salah satu kelurahan yang termasuk dalam kategori zona merah. Selain itu, kelurahan lasiana secara geografis terletak di pinggiran kota Kupang dengan jumlah masyarakat non ASN atau pekerja harian yang tinggi.

Sebelum melakukan kegiatan pengabdian, tim terlebih dahulu berkoordinasi dengan pemerintah setempat untuk melakukan pendataan jumlah masyarakat yang perlu mendapatkan paket bantuan. Paket bantuan bagi masyarakat masing-masing terdiri dari beras sebanyak 6 
$\mathrm{kg}$, telur ayam 30 butir, gula pasir $1 \mathrm{Kg}$, sabun cuci (detergen) $1 \mathrm{Kg}$, masker medis 3 lapis sebanyak 20 lembar dan Vitamin C $50 \mathrm{mg}$ sebanyak 45 tablet. Total paket bantuan yang dibagikan sebanyak 26 paket (Gambar 4).

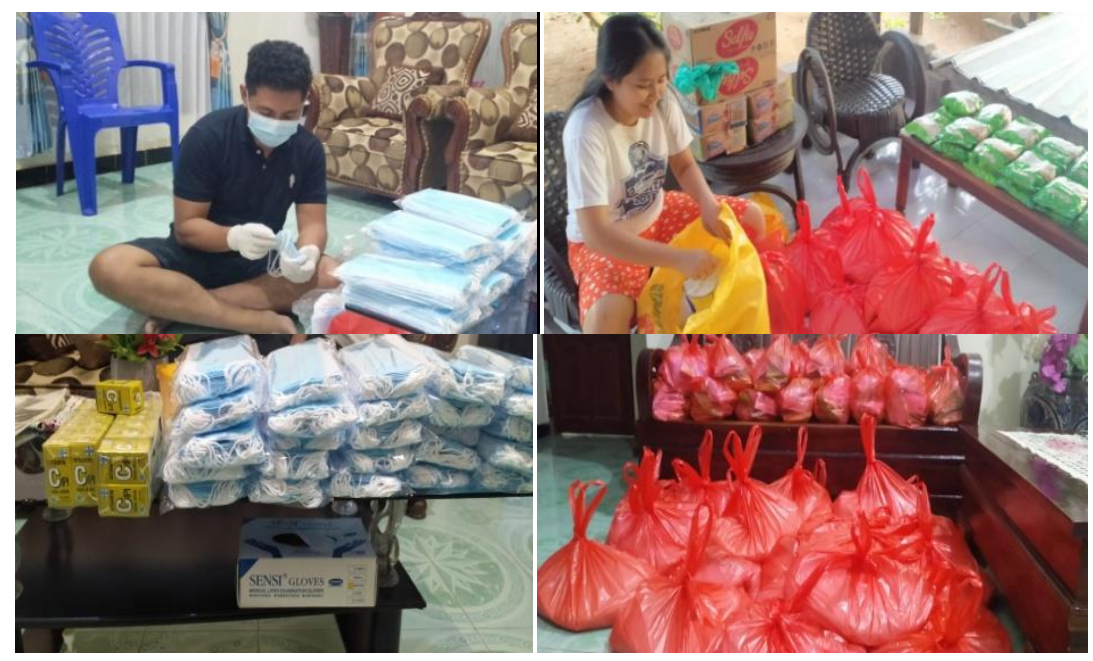

Gambar 4. Proses Persiapan paket bantuan masker medis dan vitamin $\mathrm{C}$ serta sembako

Karena kondisi pandemi dan pelaksanaan PPKM di Kota Kupang, maka Penyuluhan dilakukan dengan membagikan brosur mengenai COVID-19 dan upaya pencegahannya, termasuk informasi yang benar mengenai vaksin COVID-19 (Gambar 5). Kegiatan pengabdian kepada masyarakat dilakukan pada hari Rabu tanggal 07 Juli 2021 sejak pukul 08.00 hingga 12.00 WITA.

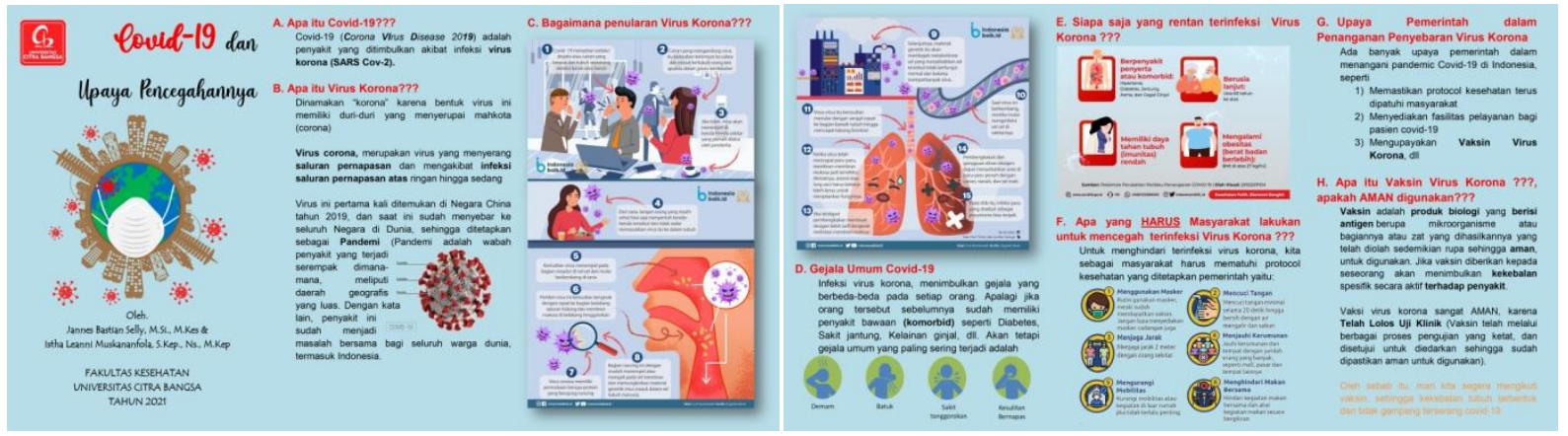

Gambar 5. Persiapan materi edukasi mengenai COVID-19 dan upaya pencegahannya, termasuk informasi yang benar mengenai vaksin COVID-19 dalam bentuk brosur 


\section{HASIL, PEMBAHASAN DAN DAMPAK}

Penyebaran COVID-19 di Indonesia sampai dengan saat ini masih terus ada dan masih menjadi masalah global (pandemik). Upaya vaksin yang ditetapkan pemerintah dapat meningkatkan kekebalan tubuh masyarakat, dan akan menekan laju penularan COVID-19. Akan tetapi usaha ini perlu mendapat perhatian khusus karena jumlah penerima vaksin yang masih kurang dari 50\% masyarakat. Kondisi ini diakibatkan adanya informasi yang keliru mengenai produk vaksin COVID-19 sehingga masyarakat ragu bahkan takut untuk melakukan vaksin. Kegiatan pengabdian dilakukan dengan tujuan memberikan edukasi yang benar tentang COVID-19 dan upaya pencegahannya, termasuk informasi yang benar mengenai vaksin COVID-19.

Pelaksanaan kegiatan dilakukan dengan mengikuti protokol kesehatan secara ketat. Pembagian dilakukan di rumah pemerintah setempat, dalam hal ini ketua RW 009 Kelurahan Lasiana (Gambar 6a), dan juga mengunjungi satu per satu rumah warga lainnya yang akan diberikan bantuan paket sembako untuk menghindari terjadinya kerumunan (Gambar 6b). Sambil melakukan pembagian bantuan sembako tim juga mengamati jika ada warga yang didapati tidak mematuhi protokol kesehatan, seperti berkerumun dan tidak menggunakan masker maka tim akan melakukan edukasi, memberikan brosur materi serta membagikan masker untuk digunakan.
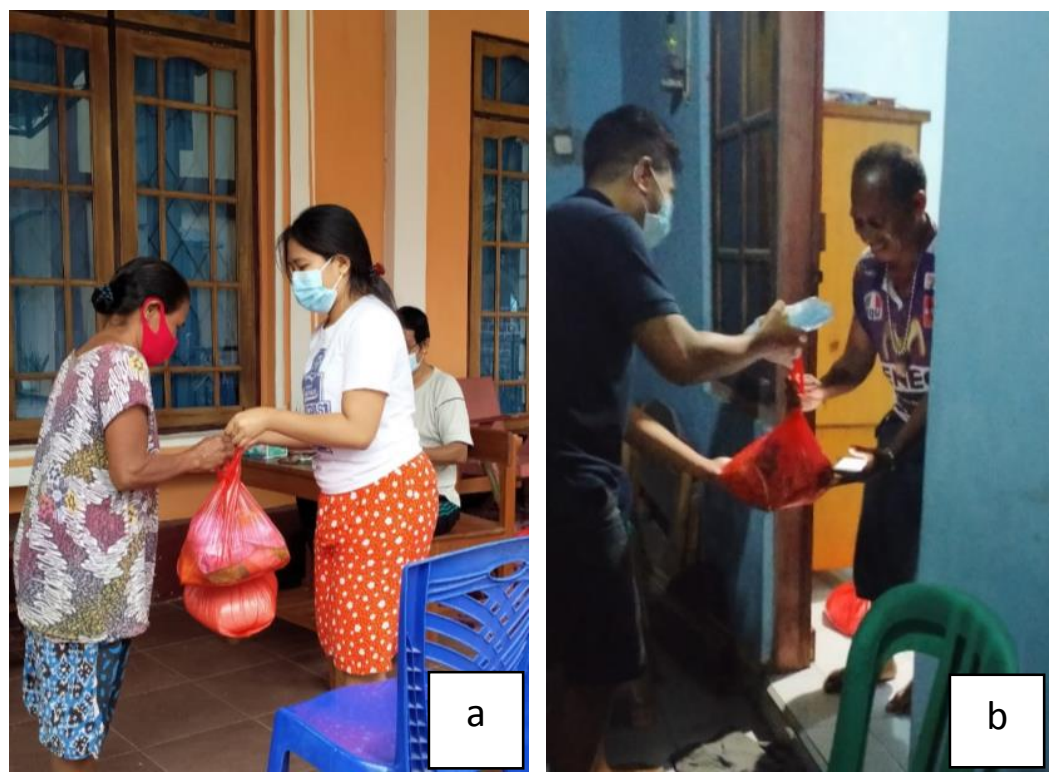

Gambar 6a. Proses pembagian paket bantuan sembako masker medis dan vitamin $\mathrm{C}$ serta edukasi bertempat di rumah salah satu ketua RW setempat Gambar $6 \mathbf{b}$ proses pembagian paket bantuan sembako, masker medis dan vitamin $\mathrm{C}$ serta edukasi di rumah warga 
Saat pelaksanaan kegiatan, masyarakat yang ditemui umumnya tidak menggunakan masker meskipun berada di tempat umum. Tim memberikan edukasi mengenai pentingnya penggunaan masker untuk meminimalisir kemungkinan penularan COVID-19. Setelah itu tim membagikan masker untuk digunakan. Saat diberikan, masker langsung digunakan oleh masyarakat Hal ini menunjukkan bahwa dengan adanya edukasi yang baik, masyarakat dapat mengikuti protokol. Jika dilakukan secara terus menerus, maka akan menjadi kebiasaan baik yang akan terus dilakukan.

Pembagian bantuan sembako juga mendapatkan apresiasi bukan hanya dari masyarakat, juga dari pemerintah setempat. Masyarakat mengatakan bahwa paket sembako yang diberikan sangat membantu, terutama dalam kondisi penerapan PPKM saat ini. Penerapan PPKM membuat masyarakat terbatas dalam melakukan kegiatan sehari-hari sehingga berpengaruh terhadap pendapatan masyarakat, khususnya masyarakat yang tidak memiliki pekerjaan tetap. Paket bantuan sembako setidaknya dapat membantu masyarakat memenuhi kebutuhan pokok minimal selama penerapan PPKM selama 2 minggu kedepan.

Materi edukasi tentang COVID-19 yang disampaikan bagi masyarakat adalah tentang pemahaman tentang: a) apa itu pandemi COVID 19; b) apa itu virus corona; c) bagaimana virus corona dapat menular; d) apa saja gejala umum COVID-19; e) siapa saja yang rentan terinfeksi COVID-19; f) apa saja protokol kesehatan yang harus dilakukan masyarakat untuk mencegah penularan COVID-19; g) apa saja upaya yang dilakukan pemerintah dalam penanganan penyebaran COVID-19, serta h) apa itu vaksin COVID-19 dan bagaimana tingkat keamanannya untuk digunakan.

Pada saat edukasi mengenai pentingnya mendapatkan vaksin dan keamanan vaksin COVID-19, tim menjelaskan bahwa vaksin yang saat ini sudah beredar dan digunakan masyarakat, telah melewati berbagai tahap uji, baik uji pre klinis, yaitu pengujian pada hewan percobaan, hingga uji klinis yang dilakukan pada manusia dalam 3 tahapan berbeda. Apabila ada 1 saja tahapan yang gagal dalam pengujian, maka vaksin tidak akan diedarkan dan digunakan. Dengan demikian vaksin yang saat ini sudah beredar di masyarakat, sangat aman untuk digunakan. Tim juga memaparkan bahwa vaksin sudah diberikan kepada para pejabat Negara seperti Presiden, para menteri, hingga public figure seperti tokoh masyarakat, tokoh agama hingga artis-artis terkenal. Oleh sebab itu, jangan ragu dan segera lakukan vaksin Pada akhir sesi edukasi, tim memotivasi serta mengajak masyarakat yang belum mendapatkan 
vaksin untuk segera menuju ke fasilitas kesehatan atau layanan lainnya yang menyediakan vaksin COVID-19.

Tim pengabdian telah melakukan evaluasi terhadap dampak dari edukasi ini, dan diketahui bahwa hasil kegiatan ini membuat semua masyarakat yang menjadi sasaran kegiatan mengerti dan memahami pentingnya vaksin, serta berkomitmen untuk segera melakukan vaksin. Evaluasi yang dilakukan berupa pemberian umpan balik setelah dilakukan edukasi mengenai keamanan vaksin bagi masyarakat. Umpan balik yang diberikan berupa pertanyaan untuk mengetahui sejauh mana pemahaman masyarakat mengenai pandemik COVID-19 serta keamanan vaksin. Respon yang diberikan masyarakat terhadap umpan balik yang diberikan tim pengabdian menunjukan bahwa masyarakat sepenuhnya telah memahami tentang materi edukasi yang diberikan. Respon lain yang diberikan masyarakat adalah dengan menyatakan komitmennya untuk bersedia menerima vaksin. Selanjutnya masyarakat yang berkomiten untuk menerima vaksin didata oleh tim dan diserahkan kepada pemerintah setempat dalam hal ini RT atau RW untuk melakukan tindak lanjut, hingga memastikan bahwa masyarakat telah mendapatkan vaksin dengan dosis lengkap.

\section{SIMPULAN}

Pelaksanaan kegiatan pengabdian berupa Edukasi Keamanan Vaksin dan Pembagian Sembako, Masker serta Vitamin C Sebagai Upaya Pencegahan Penularan COVID-19 dalam masa PPKM di Kelurahan Lasiana-Kota Kupang berjalan dengan baik berkat dukungan pemerintah, masyarakat maupun institusi pendidikan, dalam hal ini Universitas Citra Bangsa. Kegiatan pengabdian juga memberikan hasil yang baik terlihat dari pemahaman masyarakat mengenai materi edukasi yang diberikan, dibuktikan dengan respon masyarakat ketika tim pengabdian memberikan umpan balik setelah memaparkan materi edukasi mengenai keamanan vaksin COVID-19. Hal lain yang menjadi bukti keberhasilan kegiatan ini adalah komitmen masyarakat untuk mendapatkan vaksin COVID-19, sehingga tim pengabdian langsung membuat pendataan dan menyerahkan pada pemerintah setempat untuk dilakukan tindak lanjut. Kegiatan pengabdian ini juga memberikan manfaat lain dimana masyarakat sangat berterimakasih atas pemberian bantuan sembako yang sangat membantu pemenuhan kebutuhan pokok selama penerapan PPKM di Kota Kupang dua minggu kedepan. Kegiatan 
pengabdian seperti ini perlu terus dilakukan secara berkala bagi masyarakat sehingga tidak ada informasi yang keliru yang diterima oleh masyarakat.

\section{DAFTAR PUSTAKA}

BPS NTT. (2020). Analisis Hasil Survey Dampak Covid-19 Terhadap Pelaku Usaha Provinsi Nusa Tenggara Timur. Penerbit Badan Pusat Statistik Provinsi Nusa Tenggara Timur. No. ISBN: 978-602-6786-53-1

Dewi, S. A. E. (2021). Komunikasi Publik Terkait Vaksinasi Covid 19. HEALTH CARE: JURNAL KESEHATAN, 10(1), 162- 167. Doi: 10.36763/healthcare.v10i1.119

Kementerian Dalam Negeri RI. (2021). Instruksi Menteri Dalam Negeri Nomor 15 Tahun 2021 Tentang Pemberlakuan Pembatasan Kegiatan Masyarakat Darurat Corona Virus Disease 2019 di Wilayah Jawa dan Bali. https://setkab.go.id/mendagri-terbitkaninstruksi-tentang-ppkm-darurat-jawa-bali/ diakses pada 07 Juli 2021 Pukul 12.10 WITA

Komite Penanganan COVID-19 dan Pemulihan Ekonomi Nasional. (2021). Peta Sebaran COVID-19 di Indonesia. Sumber Berita Online URL Link https://covid19.go.id/peta-

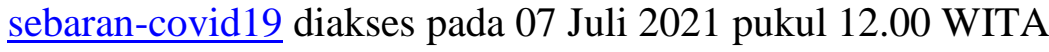

MacIntyre, C. R., Costantino, V., and Trent, M. (2021). Modelling of COVID-19 vaccination strategies and herd immunity, in scenarios of limited and full vaccine suplly in NSW, Australia. Vaccine Journal https://doi.org/10.1016/j.vaccine.2021.04.042

Pemerintah Kota Kupang (2021). Surat edaran walikota kupang tentang PPKM skala mikro di kota kupang No. 037/HK.443.1/VI/2021. Sumber Website resmi pemerintah Kota Kupang URL link https://kupangkota.go.id/2021/06/24/edaran-walikota-kupangtentang-ppkm-skala-mikro-di-kota-kupang/

Priastuti, C.W., Pawito, Rahmanto A.N. 2020. Hoaks tentang Vaksin Covid-19 di Tengah Media Sosial. Prosiding Seminar Nasional Unimus Volume 3 tahun 2020. Halaman 391399. eISSN 2654-3168

Satuan Tugas COVID-19 Pemerintah Kota Kupang (Satgas COVID-19 Pemkot Kupang). (2021). Data Monitor Harian Kewaspadaan Infeksi COVID-19 Kota Kupang. Sumber https://kupangkota.go.id/2021/07/05/info-covid-19-senin-5-juli-2021/

Thunstrom, L., Ashworth, M., Finnoff, D., and Newbold, S. (2020). Hesitancy Towards a COVID-19 Vaccine and Prospects for Herd Immunity. SSRN electronic Journal http://dx.doi.org/10.2139/ssrn.3593098 